\title{
A systematic survey of online trade: trade in Saiga antelope horn on Russian-language websites
}

\author{
David L. Roberts, Katya Mun and E. J. Milner-Gulland
}

\begin{abstract}
Trade in wildlife is increasingly moving online, which creates significant challenges for monitoring. Numerous reports have highlighted the extent of the trade but they rarely present a methodology to facilitate replication or any form of meta-analysis. Here we present a systematic approach to surveying online trade in wildlife that builds on the well-established systematic evidence review approach. We apply this approach to investigate the online trade in saiga antelope Saiga tatarica horns on Russianlanguage websites. Of the 419 advertisements, the majority $(217,52 \%)$ were from Ukraine, followed by Russia (122, $29 \%)$, and were largely offers to sell $(254,61 \%)$, and represented one-off advertisements. Trade was identified on 89 websites, with the majority being on classified ads websites $(68,76 \%)$, auction.violity.com being the most popular site $(156,37 \%)$. Prices varied significantly depending on the country and how the horn was being offered (i.e. by weight or length). It is clear that saiga horn is being traded over the internet, with Ukraine and Russia comprising c. $80 \%$ of advertisements on Russian-language websites. Individuals with single advertisements dominate, suggesting website fidelity, although website usage is country-specific, potentially reflecting domestic trade. This suggests country-specific interventions could be particularly effective. A systematic approach for investigating online wildlife trade provides a clear and transparent methodology, and, given data collection is resource-intensive, allows studies to be replicated so that trends can be identified. However, this is only possible if published studies report the methodology used.
\end{abstract}

Keywords CITES, demand-side, enforcement, illegal wildlife trade, internet, Saiga tatarica, supply-side, traditional Asian medicine

Supplementary material for this article is available at doi.org/10.1017/So030605320001313

DAVID L. RoBERTs ${ }^{*}$ (Corresponding author, (1) orcid.org/0000-0001-6788-2691) Durrell Institute of Conservation and Ecology, School of Anthropology and Conservation, University of Kent, Marlowe Building, Canterbury, Kent, CT2 7NR, UK. E-mail d.l.roberts@kent.ac.uk

KATYA Mun Independent Researcher, Tashkent, Uzbekistan

E. J. Milner-Gulland Department of Zoology, University of Oxford, Oxford, UK

*Also at: Department of Zoology, University of Oxford, Oxford, UK

Received 31 July 2020. Revision requested 13 October 2020.

Accepted 10 November 2020. First published online 27 April 2021.

\section{Introduction}

The trade in wildlife, both legal and illegal, is moving in1 creasingly onto the internet, where trade can take place without being limited to particular days or times, and buyers and sellers can connect with minimal personal risk (Harrison et al., 2016; Di Minin et al., 2018). Although a number of organizations have investigated the online trade in wildlife (e.g. Hastie \& McCrea-Steele, 2014; TRAFFIC, 2019), the resulting reports often lack a methodology that is sufficiently detailed (e.g. search terms used, number of individuals conducting the search, frequency of visits to websites, whether snowball sampling was used to find additional items) to allow the study to be replicated and thus changes to be monitored over time (but see Brace \& Dean, 2018; Xin \& Xiao, 2019). Such reports are more often produced to garner support for interventions in cyber-enabled illegal wildlife trade rather than as research outputs, but it would be beneficial for such studies to post a detailed methodology online along with, where possible, the associated data as supplementary materials (Lee \& Roberts, 2020). Currently, many studies appear ad hoc, lacking a rigorous methodology that would maximize the utility of the data, which is time-consuming to collect. An explicit systematic approach is required for collecting data about online wildlife trade, to track trends robustly and to support evaluation of the impact of any interventions.

With its basis in medicinal evidence (Higgin \& Green, 2011), the use of the systematic evidence review approach is well established within conservation and environmental sciences (Pullin \& Stewart, 2006), and elsewhere (e.g. crime; Braga et al., 2018). The systematic evidence review framework provides a method of gathering evidence from a structured survey of the literature in a systematic form, to allow well-defined questions to be addressed. In the same way as literature can be searched in a systematic manner, so too can online markets. Here we use a systematic survey protocol for undertaking online surveys of wildlife trade, with the aim of allowing data to be collected in a rigorous and transparent manner.

Research to date on the online trade in wildlife has focused on a limited number of platforms (e.g. eBay, Alfino \& Roberts, 2018; Facebook, Xu et al., 2020) and/or a specific country (e.g. Thailand, Phassaraudomsak et al., 2019) or language (often English). Furthermore, much of this research has been focused on the demand rather than the supply side of the trade. This may be a result of internet structure and/or the use of e-commerce within least developed and 
lower middle income supply-side countries where the internet is less developed and/or available to users (e.g. Hastie, 2017). Here, we apply the systematic survey approach to a survey of the online trade in raw saiga antelope Saiga tatarica horn on Russian-language websites that are in wide use within range, former range and neighbouring states. To our knowledge, this is the first survey of online trade in saiga products, although there have been previous surveys of physical markets (e.g. Li et al., 2007; von Meibom et al., 2010).

The saiga antelope once roamed the central Asian steppe from the Ukraine in the west, to China and Mongolia in the east (Bekenov et al., 1998). Currently the species is confined to populations in Kazakhstan, the Russian Federation, Uzbekistan (S. tatarica tatarica) and Mongolia (S. tatarica mongolica), and is categorized as Critically Endangered on the IUCN Red List. There are a few small captive populations within the current range states and in China, and one larger free-roaming captive population at Askania Nova in the Ukraine (Glazer, 2017). Because the saiga is a migratory species, changes to the landscape through habitat loss and transport infrastructure projects are a significant threat (Convention on Migratory Species, 2015c). In addition, recent mass-mortality events, caused by Pasteurella multocida type B bacteria leading to haemorrhagic septicaemia in Kazakhstan (Kock et al., 2018), and the peste des petits ruminants virus in Mongolia (Aguilar et al., 2018), have devastated populations.

The major cause of saiga decline since the late 1990s, however, has been illegal and unregulated hunting for their meat and horns following the break-up of the Soviet Union (Milner-Gulland et al., 2001; Kühl et al., 2009). Because only males bear horns, selective hunting for the horns for export for traditional Chinese medicine led to a significant distortion in the sex ratio of populations, and reproductive failure (Milner-Gulland et al., 2003). The saiga has been listed on Appendix II of CITES since 1995, and range states have had moratoria on hunting and export of saiga products since the 2000s. During 2007-2016, small amounts of saiga horn, both raw and processed, were legally traded between consumer countries (mostly China, Singapore and Japan; CITES, 2018). However, at the 2019 CITES Conference of the Parties, a zero quota was agreed, meaning that legal trade between non-range states has now also stopped (CITES, 2019). Saiga products sold online are legal if the product is to be used domestically in compliance with the country's national legislation. Domestic sale of saiga products in mainland China and Japan requires official approvals, and domestic trade is illegal in Russia, Uzbekistan and Kazakhstan (CITES, 2018). Elsewhere there appears to be no specific regulations related to domestic trade. Recent surveys of consumer demand for saiga horn products in Singapore suggested there is still relatively high domestic demand for these products, which can be freely sold because Singapore has declared a domestic stockpile (Theng et al., 2018; Doughty et al., 2019).

Following a systematic survey approach (Supplementary Material 1), we aim to determine the extent of trade in saiga, specifically raw horns, over Russian-language platforms (including but not limited to classified advertisements, shopping and social media platforms), in range, former range and neighbouring countries, during the study period and the 12 months prior to the start of the study. We also aim to show the utility of the systematic survey approach described here, using the online trade in saiga horns as an example.

\section{Methods}

Our systematic approach to the online survey, following the well-established systematic evidence review approach (Higgins \& Green, 2011), is described in detail in Supplementary Material 1 . We aimed to facilitate future replication of the study so that trends may be identified. We considered the following matters in developing the scope of the study and the search strategy. (1) Production origin: we did not specify whether the trade was of wild or farmed origin as CITES rules cover both. (2) Geographical origin: we did not specify a geographical origin; we are unaware of any evidence that, from the point of view of consumers, there are differences between saiga products from particular geographical locations. (3) Period of trade: the survey was undertaken during April-August 2018, and we considered trade during this period and any trade up to 1 year earlier (April 2017); i.e. a 17-month period. (4) Trade behaviour: we considered all forms of trade, in this case both buyers and sellers. (5) Population: we specifically searched for trade in S. tatarica, including both S. tatarica tatarica and $S$. tatarica mongolica, although we did not specify either subspecies during the search. (6) Product: we looked specifically for trade in raw horns rather than finished products such as knife handles or shavings, or other products such as hunting trophies. (7) Platform: we were interested in trade over all open Russian-language websites, based on a search through google.com and yandex.ru. (8) Country of trade: we were not interested in trade from a specific country. (9) Origin of trade: we were not interested in trade originating from a specific country. Although we did not consider a specific country or countries, searching open Russian-language websites focused on range, former range and neighbouring states. Even in states with other official languages (such as Kazakhstan and Uzbekistan), Russian is widely spoken and use of Russian-language platforms is the norm.

Following a discussion with saiga experts and based on the considerations described above, we used a set of Russian-language search terms related to saigas, horn and trade (Table 1; Supplementary Material 1) for the survey of 
TABLE 1 Logic grid for traded species and trade terms. Only the Russian terms were included in the searches. The Russian name for saiga Saiga tatarica is generally Сайгак and the most usual way to express saiga horn is Рог Сайгака, but we also used other terms in common usage.

\begin{tabular}{lll}
\hline Terms & English terms & Russian terms \\
\hline Taxa & Saiga & Сайгак (nominative, masculine) \\
& Saiga & Сайгака (genitive, masculine) \\
& Saigi & Сайги (genitive, feminine) \\
& Saigachi & Сайгачьи (possessive adjective) \\
& Antelope & Антилопа (nominative) \\
\multirow{5}{*}{ Product } & Antelope & Антилопы (genitive) \\
& Horn & Рог \\
& Horns & Рога \\
& Buy & Куплю \\
& Sale (I will sell) & Продам \\
& Sale (I sell) & Продаю \\
\hline
\end{tabular}

online trade in saiga horn. As we were only interested in raw saiga horn, rather than worked horn or other finished products (e.g. traditional Asian medicines), the search terms knife and handle (нож, пчак, рукоятка) were excluded.

Using these search terms (Table 1), the first 200 results from the search engines google.com and yandex.ru were investigated; the latter search engine is more popular in Russian-speaking countries. However, it became apparent that the search engines are not sensitive to morphology (i.e. gender, case, number, declination) and therefore we used the logical expression OR (or yandex.ru equivalent) to combine searches on saiga and antelope. This resulted in two searches on each of the search engines, with the sole difference being the use of the term for buy or sell: (1) куплю рога (сайгака | антилопы); (2) продам рога (сайгака | антилопы). When a website was identified on which saiga horn was being advertised, a search was conducted within the particular website using the same search terms to identify further advertisements. These websites were then visited repeatedly to identify new advertisements during the 5-month period 1 April-31 August 2018.

From the search results, we recorded the data for each item as described in Table 2. Duplicate advertisements (assessed based on similarity of text and images used) were removed. These were advertisements that displayed the same product or offer, published by the same person on the same site. Price data was converted to USD because of the number of countries considered in the study; even within individual countries, on 10 occasions prices were given solely in USD (one in each of Moldova, Russia, Ukraine and Uzbekistan; six for Belarus). Conversion to USD was based on the website $\mathrm{XE}$ (2021) using the midpoint between the highest and lowest price during 2017-2018.

\section{Analysis}

Wilcoxon rank-sum tests with continuity correction and Kruskal-Wallis tests were calculated using $R$ 3.6.2 (R Core Team, 2019) to examine differences in price by country. As saiga horn was traded by weight and/or length, we used regression analysis for conversion between these units when analysing price data.

\section{Results}

In total 419 advertisements were identified, of which $89 \%$ resulted from a search of yandex.ru and $11 \%$ from google.com. Of the 419 advertisements, the majority ( $52 \%$ ) originated in the Ukraine, followed by Russia (29\%) and Belarus (14\%). There were no advertisements from Mongolia or Turkmenistan (Table 3 ). The advertisements comprised $61 \%$ offers to

TABLE 2 Description of variables recorded for each item based on a search for the online trade in raw saiga horn.

\begin{tabular}{|c|c|}
\hline Variable & Description \\
\hline Date of advertisement & Date advertisement was placed \\
\hline Buyer/Seller & Whether offering to sell or buy saiga horn \\
\hline Quantity & Number of horns offered for sale or they wished to buy \\
\hline Weight & Number of $\mathrm{kg}$ for sale or they wished to buy \\
\hline Length & Length in $\mathrm{cm}$ of horn for sale or that they wished to buy \\
\hline Total price & The total price for the item for sale or they wished to buy \\
\hline Price & Price per kg \\
\hline Platform & $\begin{array}{l}\text { Type of website on which the advertisement was placed: 'classified advertisements' (general websites containing a } \\
\text { variety of items for sale, but that lack an integrated purchasing system such as a shopping cart facility); 'trading' } \\
\text { (general website with an integrated purchasing system); open 'social media' \& 'specific' websites (website } \\
\text { dedicated to the sale of saiga horns \& other related derivatives) }\end{array}$ \\
\hline Link & URL to the item \\
\hline Telephone & Phone number associated with the advertisement \\
\hline Country of trade & Country where the seller \&/or item is indicated as being located or the buyer is indicated as being located \\
\hline City & City where the seller \&/or item is indicated as being located or the buyer is indicated as being located \\
\hline Shipping & Where the seller is willing to ship the item to \\
\hline
\end{tabular}


TABLE 3 Relationship between buyers and sellers by country.

\begin{tabular}{lccrc}
\hline Country & Total no. of advertisements & No. of advertisements to buy & No. of advertisements to sell & Ratio of buy to sell \\
\hline Belarus & 60 & 59 & 1 & 59.0 \\
Kazakhstan & 12 & 2 & 10 & 0.2 \\
Moldova & 5 & 4 & 1 & 4.0 \\
Russia & 122 & 47 & 75 & 0.6 \\
Ukraine & 217 & 51 & 166 & 0.3 \\
Uzbekistan & 1 & 0 & 1 & 0.0 \\
\hline
\end{tabular}

sell and 39\% offering to buy saiga horn; one advertisement was an offer to buy and sell saiga horn. We encountered both regular and one-off advertisements. Of the 419 advertisements, $54 \%$ were sellers with a single advertisement and $39 \%$ were buyers with regular advertisements; $6 \%$ were regular sellers and one individual was a buyer and seller with regular advertisements. Belarus was dominated by buyers, and sellers dominated trade in the Ukraine, and to a lesser extent in Russia (Table 3).

For the 235 advertisements (56\%) that contained location information in the text, all countries were well represented, with $>80 \%$ of the advertisements in most countries containing location information. The exception was Ukraine, with only $29 \%$ of its 217 advertisements containing location information, a result of only $6 \%$ of the 156 advertisements on auction.violity.com in the Ukraine containing location data. Advertisements were placed from 79 cities and other unique locations, with the top three being Moscow (Russia) with 32 (14\%) advertisements, Minsk (Belarus) with 30 (13\%) and Kharkiv (Ukraine) with 15 (6\%). Both Minsk- and Kharkivbased advertisements were solely offers to buy and Moscow was dominated by offers to sell (84\% of Moscow's 32 advertisements).

Two hundred and forty sellers stated the quantity of saiga horn offered for sale in terms of number of horns, ranging from one to 14 horns, with $86 \%$ offering one or two horns. Little information was provided regarding where those advertising saiga horn were willing to ship to (37 advertisements; $9 \%$ of the sample), with 30 advertisements (7\%) stating they would ship within the country where the item was advertised and seven stating they would ship internationally; none of the advertisements mentioned CITES permits.

\section{Website type and usage}

We found advertisements across 89 websites, of which general classified advertisement websites were the most frequent type (76\%), followed by websites dedicated to the sale of horns or derivatives of horns (15\%); trading and open social media websites accounted for 6 and $3 \%$, respectively. The majority of the 419 advertisements were on classified advertisement (49\%) and trading (42\%) websites, with few on open social media $(5 \%)$ or specialist websites $(3 \%)$.
The most frequently used website was auction.violity. com $(n=156 ; 37 \%)$, but all these advertisements were from Ukraine, representing $72 \%$ of the 217 advertisements from this country. Only two websites, chinadftzalex.com and slanet.by, had advertisements with known locations in more than one country. The website chinadftzalex.com contained 19 advertisements (16 from Russia and one each from Kazakhstan, Moldova and Ukraine), and slanet.by contained 15 advertisements (14 from Belarus and one from Russia). The platform olx was used in three countries to trade in saiga horn (Kazakhstan, $\mathrm{n}=7$, olx.kz; Ukraine, $\mathrm{n}=8$, olx.ua; Uzbekistan, $\mathrm{n}=1$, olx.uz), representing countryspecific marketplaces.

Nearly half ( $n=207 ; 49 \%)$ of the 419 advertisements provided contact details in the form of telephone numbers, potentially representing 158 unique users. Based on the assumption that these are unique identifiers, the majority of buyers and sellers had a single advertisement $(n=129$; $82 \%$ ); however, one individual had 8 unique advertisements. Eighty-five per cent $(n=135)$ of buyers and sellers advertised on a single website, with one individual having advertisements on seven websites; the individual with the most advertisements (eight) only advertised on two websites. When considering those that published multiple advertisements $(n=29)$, the majority placed one advertisement per website $(n=20)$. However, although we used telephone numbers as a unique identifier, three supposedly unique individuals posting six advertisements had sequential telephone numbers. All six advertisements were from the Ukraine, with five from the same city and one without a city listed.

\section{Pricing}

Of advertisements that provided price per $\mathrm{kg}(\mathrm{n}=54)$, the price of saiga horn was USD 7.38-594.41 per kg. However, pricing data was highly skewed, with a median price of USD 49.36 per $\mathrm{kg}$. Price in Russia was significantly higher (Kruskal-Wallis $\chi^{2}=7.7452, \mathrm{df}=2, \mathrm{P}=0.021, \mathrm{n}=20$; median USD 200.81 per $\mathrm{kg}$ ) than in Ukraine $(\mathrm{n}=20$; median USD 55.34 per $\mathrm{kg})$ and Belarus $(\mathrm{n}=10$; median USD 22.00 per $\mathrm{kg}$ ). Prices in Moldova ( $\mathrm{n}=3$; USD 18.42 per $\mathrm{kg}$ ) and Kazakhstan ( $\mathrm{n}=1$; USD 175.50 per $\mathrm{kg}$ ) could not be compared statistically because of the small sample sizes. 
Of the remaining advertisements, 132 provided only weights of the horn being sold, from which we calculated price per kg. Median prices for these items were higher than those advertised in $\mathrm{kg}$, at USD 211.32 per $\mathrm{kg}$, but varied considerably (USD 1.68-777.34 per kg). Again, price in Russia was significantly higher (Wilcoxon rank-sum test with continuity correction $\mathrm{W}=1,111, \mathrm{P}=0.008, \mathrm{n}=13$; median USD 306.00 per $\mathrm{kg})$ than in Ukraine $(\mathrm{n}=118$; median USD 208.83 per kg); Uzbekistan had one item offered, at USD 400.00 per $\mathrm{kg}$.

Seventy-five advertisements provided both the weight $(\mathrm{kg})$ and length $(\mathrm{cm})$ of the horn offered for sale. These data were used to develop a predictive model to estimate the weight of horn when only the length was available. A power regression provided a better fit $\left(r^{2}=0.432 ; y=2 \times 10^{-05} x^{2.8717}\right)$ than either a linear regression $\left(r^{2}=0.237 ; y=0.0242 x-0.03143\right)$ or an exponential regression $\left(r^{2}=0.391 ; y=0.0161 \mathrm{e}^{0.1057 \mathrm{x}}\right)$. Weights were estimated using the equation for the power regression line for the 53 advertisements that only contained the length of the horn. Based on these estimated weights, the median price per $\mathrm{kg}$ was lower than either of the previous two measures of price per $\mathrm{kg}$, at USD 23.34 per $\mathrm{kg}$ (USD 0.03-123.22 per kg). Price in Russia was again significantly higher (Wilcoxon ranksum test with continuity correction $W=501, \mathrm{P}=0.002, \mathrm{n}=20$; median USD 33.22 per $\mathrm{kg}$ ) than in Ukraine $(\mathrm{n}=33$; median USD 17.08 per $\mathrm{kg}$ ). The stated weight was consistently the best predictor of price compared with stated length or the modelled weight, with a linear relationship providing the best fit (Table 4).

\section{Discussion}

The online trade in saiga horn on Russian-language websites appears to be dominated by Ukraine, accounting for over half the trade, with over three-quarters of their trade being sellers, even though the only potential domestic source is the captive population at Askania Nova in the south of the country. Askania Nova has been reportedly (G. Glazer, pers. comm., 2017) selling animals, legally, to cover costs, and some of these sales may be reflected in the online trade statistics. Russia had the second highest levels of trade and, like Ukraine, it was dominated by sellers. This is less surprising given that Russia has wild and captive saiga populations, but is of concern as all trade in saiga products is illegal under the Russian criminal code (Convention on Migratory Species, 2015b). Belarus had the third highest levels of trade, dominated by buyers. That there are few sellers is unsurprising as the saiga does not occur in the country, but it is unclear why people in Belarus would want to buy horn. The level of demand for saiga horn from Belarus requires investigation.

The implications of the price differences we found are difficult to discern without further information. Saiga horn degrades over time, and so it may be that the horns offered in the non-range states (such as Belarus or Moldova) are of poorer quality as they may be older material. Prices might be expected to be lower earlier in the supply chain, where supply is more plentiful and the cumulative risks of interception and prosecution are lower (e.g. Kazakhstan). It may be that in Russia prices can be set higher because of higher prices generally. Alternatively sellers may not have a well-developed awareness of the market, with variation in prices a result of an immature or opportunistic market in which vendors are testing the market with unrealistically high prices.

Saiga horn is not sold in physical markets in the range states; rather, it is sold privately through criminal networks. Posters offering to buy and sell horn, with a phone number, are sometimes observed pasted in public spaces. There is some additional, limited information on the price of saiga horn, based on key informant interviews. In the early 200os, prices in Kazakhstan were estimated to be c. USD $180 / \mathrm{kg}$ (von Meibom et al., 2010). This is the same as the mean price we estimated, which suggests that real prices have decreased, given inflation. A rapid assessment in Malaysian traditional medicine stores in 2018 found whole horns priced at USD 500-2,200/kg (Gomez \& Krishnasamy, 2019).

Kazakhstan holds most of the world's saigas, but only 12 advertisements originated from there during the 17 month period of study. This low level of trade is potentially a result of the country's strict moratorium on legal trade in saiga products (Convention on Migratory Species, 2015a), as

TABLE 4 Relationship between stated length $(\mathrm{cm})$, stated weight $(\mathrm{kg})$, and modelled weight $(\mathrm{kg})$ and price (USD) of saiga horn.

\begin{tabular}{|c|c|c|c|}
\hline \multirow[b]{2}{*}{ Variable } & \multicolumn{3}{|l|}{ Regression line } \\
\hline & Linear & Exponential & Power \\
\hline Length & $\begin{array}{l}y=6.7532 x-109.86 \\
r^{2}=0.189\end{array}$ & $\begin{array}{l}y=1.2702 \mathrm{e}^{0.1348 \mathrm{x}} \\
r^{2}=0.255\end{array}$ & $\begin{array}{l}y=0.0004 \mathrm{x}^{3.5849} \\
r^{2}=0.269\end{array}$ \\
\hline Weight & $\begin{array}{l}y=231.1 x-5.5418 \\
r^{2}=0.547\end{array}$ & $\begin{array}{l}y=17.404 \mathrm{e}^{3.0737 \mathrm{x}} \\
r^{2}=0.327\end{array}$ & $\begin{array}{l}y=162.48 x^{0.9416} \\
r^{2}=0.355\end{array}$ \\
\hline Modelled weight & $\begin{array}{l}y=228.6 x+10.367 \\
r^{2}=0.167\end{array}$ & $\begin{array}{l}y=14.471 \mathrm{e}^{4.4501 \mathrm{x}} \\
r^{2}=0.214\end{array}$ & $\begin{array}{l}y=273.59 x^{1.2484} \\
r^{2}=0.269\end{array}$ \\
\hline
\end{tabular}


well as a recent initiative of the NGO Association for the Conservation of Biodiversity of Kazakhstan that focused on tackling the online trade (M. Suttibayev, pers. comm., 2019). The need for this initiative is reinforced by the continued reports of saiga poaching in Kazakhstan's media (e.g. Tengrinews, 2020). Furthermore, governments and NGOs have expressed continued concern about illegal hunting in Uzbekistan and Russia, but their relatively low saiga populations limit opportunities for domestically-sourced trade (particularly in Uzbekistan, with low hundreds of animals, compared to low thousands in Russia). Therefore it seems likely that any substantial ongoing trade in saiga horns would mostly be fed from Kazakhstan's saiga populations, given that these are far larger than the other populations. Overall, it is difficult to know whether the limited amount of trade we uncovered is because e-commerce is not an established avenue of illegal trade generally, or because the amount of online trade parallels a low level of physical trade in the species. A disparity between countries in use of the internet for the illegal wildlife trade has previously been noted in Africa (Hastie, 2017).

Some, although limited, trade appears to be taking place online in Moldova. The country has no populations of saiga, and trade appears to be dominated by buyers. Additionally, two cases of potentially illegal online trade in live saiga antelopes have been recorded in Slovakia, in late 2015 and early 2016, of potential Ukrainian origin (Glazer, 2017).

Trade in saiga horn was via a relatively high number of websites $(n=89)$, mostly classified advertisement and trading websites rather than through social media, although this may be an artefact of the fact that we only searched open websites. We detected almost no overlap in marketplaces between countries, suggesting potentially limited international reach of the online trade in saiga horn. As a result, countrybased interventions, as in Kazakhstan, may be particularly effective. Although trade was dispersed over many countrybased websites, making targeting more difficult, one website, auction.violity.com, dominated trade, with $37 \%$ of all advertisements. All these advertisements were from the Ukraine, and therefore this website represents a potential point for targeted intervention such as awareness raising and demand reduction.

In those cases where we had approximate individual identifiers (e.g. phone number), the results suggest that, as has been shown for other wildlife commodities (e.g. ivory; Yeo et al., 2017), the majority of trade is in the form of individuals placing a single advertisement. The majority of individuals placing multiple advertisements placed single advertisements on multiple websites, raising the question of whether there is a significant cost of moving between online platforms (e.g. the time required to learn how to use a new website). This website fidelity has important implications for interventions in the illegal online wildlife trade where individual websites are banning certain trades. One suggestion has been to force the surface trade onto the dark web, where trade volumes can be more easily monitored (Coalition on End Wildlife Trafficking Online, pers. comm., 2018).

In terms of legal trade, in most of the countries (except Russia and Kazakhstan where all trade is illegal), sellers that specified they would only deliver domestically were not breaking the law, and these were in the majority among the few sellers who did specify shipping rules. However, the suspected use of burner phones (i.e. disposable mobile phones) in Ukraine, based on the use of sequential phone numbers, suggests a criminal element may be involved, and the high level of trade in Belarus reflects illegal trade as it is not a range state and has no legal horn imports listed under CITES. The trade in Ukraine could be a result of sales from Askania Nova, although the country's captive population is not large enough to sustain high levels of trade, and it may be that much of this is also illegally obtained horns from Russia or other range states.

Overall, it is clear that saiga horns are being traded over the internet, although advertisements are focused on domestic trade. This may facilitate country-specific interventions (as has happened in Kazakhstan), and their effectiveness to be monitored using repeat surveys with a consistent methodology. However, the extent to which individuals would then move to alternative platforms, and potentially platforms in other countries, thus increasing the globalization of the trade, remains unclear. Furthermore, the uses to which saiga horn is put by buyers needs further investigation, given the lack of a tradition of saiga horn use for medicine or other purposes in these countries. This would allow tailored interventions to reduce demand, and could potentially uncover physical trade routes for those products to consumer countries.

Here we have shown how a systematic survey approach to investigate online trade in wildlife products can be applied. This approach provides a clear and transparent methodology, allowing confidence in the identification of future trends. Similar approaches should be considered in future studies of online wildlife trade.

Acknowledgements We thank the Saiga Conservation Alliance for funding KM, and the Oxford Martin Programme on the Illegal Wildlife Trade for funding DLR and EJM-G; the Saiga Conservation Alliance for providing expert discussion on search terms; Mukhit Suttibayev for his insights; Elena Bykova for her support; and Helen Pheasey for statistical support.

Author contributions Conception of idea: EJM-G, DLR; survey design: DLR; data collection: KM; analysis: DLR, KM; writing: DLR, with participation of other authors.

Conflicts of interest EJM-G is a Senior Editor with Oryx.

Ethical standards Ethics approval for this study was granted by the Research and Ethics Committee of the School of Anthropology and Conservation, University of Kent, and the research otherwise complied with the Oryx guidelines on ethical standards. 


\section{References}

Aguilar, X.F., Fine, A.E., Pruvot, M., Njeumi, F., Walzer, C., Kock, R. \& Shillegdamba, E. (2018) PPR Virus threatens wildlife conservation. Science, 362, 165-166.

Alfino, S. \& Roberts, D.L. (2018) Code word usage in the online ivory trade across four European Union member states. Oryx, 54, 494-498.

Bekenov, A.B., Grachev, I.A. \& Milner-Gulland, E.J. (1998) The ecology and management of the saiga antelope in Kazakhstan. Mammal Review, 28, 1-52.

Brace, S. \& Dean, C. (2018) Sounding the Horn: A Survey of Rhino Horn Antiques Sold in 2017 at Auction in the UK. Save The Rhino International. London, UK. savetherhino.org/wp-content/uploads/ 2018/10/SoundingtheHorn94ppOnline.pdf [accessed 20 October 2020].

Braga, A.A., Weisburd, D. \& Turchan, B. (2018) Focused deterrence strategies and crime control: An updated systematic review and meta-analysis of the empirical evidence. Criminology \& Public Policy, 17, 205-250.

CITES (2018) Saiga Antelope (Saiga spp.): Report of the Secretariat. Seventieth meeting of the Standing Committee Rosa Khutor, Sochi (Russian Federation), 1-5 October 2018. SC70 Doc. 58. CITES, Geneva, Switzerland.

CITES (2019) Summary Record of the Third Plenary Session. CoP18 Plen. Rec. 3 (Rev. 1). Eighteenth meeting of the Conference of the Parties Geneva (Switzerland), 17-28 August 2019. cites.org/sites/ default/files/eng/cop/18/Plen/SR/E-CoP18-Plen-Rec-03-R1.pdf [accessed 30 July 2020].

Convention on Migratory Species (2015a) Form of the National Report on the Implementation of the Memorandum of Understanding, and also the Plan of Actions for the Preservation, Resportation and Sustainable Use of Saiga Antelope. National Report of Kazakhstan. UNEP/CMS/Saiga/MOS3/Inf.10.1/Rev.1. cms.int/ sites/default/files/document/нац\%2оотчет\%2оКМB\%2008072015_ KAZ_o.pdf [accessed 30 July 2020].

Convention on Migratory Species (2015b) Form of the National Report on the Implementation of the Memorandum of Understanding, and also the Plan of Actions for the Preservation, Resportation and Sustainable Use of Saiga Antelope. National Report of Russia. UNEP/CMS/Saiga/MOS $3 /$ Inf.10.3. cms.int/sites/default/ files/document/Нац\%2оотчет\%2оKMB\%2026082015_RUS_o.pdf [accessed 30 July 2020].

Convention on Migratory Species (2015c) Overview Report on the Conservation Status and MOU Implementation. Prepared by IUCN/SSC Antelope Specialist Group \& the Saiga Conservation Alliance on behalf of the CMS Secretariat. UNEP/CMS/Saiga/ $\mathrm{MOS}_{3} /$ Doc.6, 30 September 2015. cms.int/saiga/sites/default/files/ document/Saiga\%2oMOS3_Overview_Report_of_Conservation_ Status_Eng.pdf [accessed 30 July 2020].

Di Minin, E., Fink, C., Tenkanen, H. \& Hiippala, T. (2018) Machine learning for tracking illegal wildlife trade on social media. Nature Ecology \& Evolution, 2, 406-407.

Doughty, H., Veríssimo, D., Tan, R.C.Q., Lee, J.S.H., Carrasco, L.R., Oliver, K. \& Milner-Gulland, E.J. (2019) Saiga horn user characteristics, motivations, and purchasing behaviour in Singapore. PLOS ONE, 14, eo222038.

Glazer, G. (2017) An Overview of the Saiga Antelope (Saiga tatarica) in Captivity in Europe and the United States. Report commissioned by the Saiga Conservation Alliance for presentation at the Captive Breeding Workshop, Moscow, August 2017. saiga-conservation.org/ wp-content/uploads/2017/o9/CBW-meeting-report.pdf [accessed 30 July 2020]
GomeZ, L. \& Krishnasamy, K. (2019) A rapid assessment of the trade in Saiga Antelope horn in Peninsular Malaysia. TRAFFIC Bulletin, $31,35-38$

Harrison, J.R., Roberts, D.L. \& Hernandez-Castro, J. (2016) Assessing the extent and nature of wildlife trade on the dark web. Conservation Biology, 30, 900-904.

Hastie, J. (2017) Out of Africa: Byting Down on Wildlife Cybercrime. International Fund for Animal Welfare, London, UK. s3.amazonaws.com/ifaw-pantheon/sites/default/files/legacy/\% 28Pixelated\%20Webversion\%29SAInvestigationReport_lores.pdf [accessed 30 July 2020].

Hastie, J. \& McCrea-Steele, T. (2014) Wanted-Dead or Alive: Exposing Online Wildlife Trade. International Fund for Animal Welfare, London, UK. ifaw.org/european-union/resource-centre/ wanted-dead-or-alive-exposing-online-wildlife-tra-o [accessed 30 July 2020].

Higgins, J.P.T. \& Green, S. (eds) (2011) Cochrane Handbook for Systematic Reviews of Interventions. Version 5.1. The Cochrane Collaboration, London, UK. handbook-5-1.cochrane.org [accessed 30 July 2020].

Kock, R.A., Orynbayev, M., Robinson, S., Zuther, S., Singh, N.J., Beauvais, W., Morgan, E.R. et al. (2018) Saigas on the brink: multidisciplinary analysis of the factors influencing mass mortality events. Science Advances, 4, eaao2314.

Kühl, A., Balinova, N., Bykova, E., Arylov, Y.N., Esipov, A., Lushchekina, A.A. \& Milner-Gulland, E.J. (2009) The role of saiga poaching in rural communities: linkages between attitudes, socio-economic circumstances and behaviour. Biological Conservation, 142, 1442-1449.

Lee, T.E. \& RoberTs, D.L. (2020) Moving beyond simple descriptive statistics in the analysis of online wildlife trade: an example from clustering and ordination. Tropical Conservation Science, 13, 1-10.

Li, L., Zhaо, Y. \& Bennet , E.L. (2007) Report of a Survey on Saiga Horn in Markets in China. CoP14 Inf. 14. china.wcs.org/Wildlife/ Saiga-Antelope.aspx [accessed 30 July 2020].

Milner-Gulland, E.J., Bukreeva, O.M., Coulson, T., Lushcherina, A.A., Kholodova, M.V., Bekenov, A.B. \& Grachev, I.A. (2003) Reproductive collapse in saiga antelope harems. Nature, 422, 135.

Milner-Gulland, E.J., Kholodova, M.V., Bekenov, A., Bukreeva, O.M., Grachev, I.A., Amgalan, L. \& Lushcherina, A.A. (2001) Dramatic declines in saiga antelope populations. Oryx, 35, 340-345.

Phassaraudomsak, M., Krishnasamy, K. \& Chng, S.C.L. (2019) Trading Faces: Online Trade of Helmeted and Other Hornbill Species on Facebook in Thailand. TRAFFIC Report, Cambridge, UK. traffic.org/publications/reports/hornbills-losing-their-heads-toonline-trade-in-thailand [accessed 30 July 2020].

Pullin, A.S. \& STeWART, G.B. (2006) Guidelines for systematic review in conservation and environmental management. Conservation Biology, 20, 1647-1656.

R Core Team (2019) R: A Language and Environment for Statistical Computing. R Foundation for Statistical Computing, Vienna, Austria. r-project.org [accessed 20 August 2019].

Tengrinews (2020) Three people accused of murder of Yerlan Nurgaliev sentenced to life [translated]. Tengrinews, 21 February 2020. tengrinews.kz/kazakhstan_news/troih-obvinyaemyihubiystve-erlana-nurgalieva-prigovorili-392307 [accessed 30 July 2020].

Theng, M., Glikman, J.A. \& Milner-Gulland, E.J. (2018) Exploring saiga horn consumption in Singapore. Oryx, 52, 736-743.

Traffic (2019) Combating Wildlife Crime Linked to the Internet: Global Trends and China's Experiences. TRAFFIC Report, 
Cambridge, UK. traffic.org/publications/reports/combatingwildlife-crime-linked-to-the-internet [accessed 30 July 2020]. von Meibom, S., Vaisman, A., Neo Liang, S.H., NG, J. \& Hongfa, X. (2010) Saiga antelope trade: global trends with a focus on South-East Asia. TRAFFIC project report to the CITES Secretariat. TRAFFIC Europe, Cambridge, UK. trafficj.org/publication/10-Saiga_Antelope_Trade.pdf [accessed 30 July 2020].

XE (2021) XE Currency Converter - Live Rates. xe.com [accessed 14 January 2021].
XIN, W. \& XIAO, Y. (2019) Wildlife Cyber Crime Trends in China. TRAFFIC Briefing, Cambridge, UK. traffic.org/site/assets/files/ 11892/wildlife_cyber_crime_trends_in_china.pdf [accessed 20 October 2020].

Xu, Q., CaI, M. \& MACKey, T.K. (2020) The illegal wildlife digital market: an analysis of Chinese wildlife marketing and sale on Facebook. Environmental Conservation, 47, 206-212.

Yeo, L.M., McCrea, R.S. \& Roberts, D.L. (2017) A novel application of mark-recapture to examine behaviour associated with the online trade in elephant ivory. PeerJ, 5, e3048. 